\title{
Distance Education System in Physiotherapy and Rehabilitation in Turkey and Croatia
}

1 Filiz Can

2 Snježana Schuster

1 Hacettepe University Faculty of Physical Therapy and Rehabilitation, Ankara, Turkey

2 University of Applied Health Sciences - Department of Physiotherapy, Zagreb, Croatia teaching and e-learning ( $N=1403 ; 55.7 \%)$. The obtained results raise questions of students' perception of the importance of practical teaching during their university studies. The distance education system in the field of physiotherapy and rehabilitation in Turkey and Croatia will influence the revision of the curriculum and the use of a combined learning model (blended learning) also called integrated learning system.

\begin{abstract}

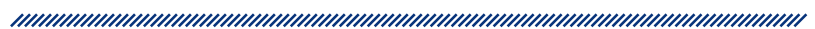

Distance education, which was implemented as a form of education in the past years, has become more important with the impact of the SARS-CoV-2 pandemic all over the world. In Turkey, since March 23, 2019, education had passed gradually to distance education at all educational levels, including physiotherapy and rehabilitation study programs at universities. There are 123 departments the Distance Education University in Turkey. $87.5 \%$ of students found the efficiency of distance education low for practical courses and $78.5 \%$ for theoretical courses. $90.3 \%$ of the students preferred traditional education and $9.7 \%$ preferred distance education. The first case of SARS-CoV-2 infection in Croatia was confirmed on February 25, 2020. In the research by Puljak et al., regarding the opinions of university students of health sciences, many students did not express concern about the lack of practical lessons, voicing opinions that this can be compensated once they start working. Most students indicated that in the future, they would prefer to combine traditional
Keywords: higher education, distance education, physiotherapy, Turkey, Croatia

Article received: 16.6.2021.

Article accepted: 1.11.2021.

https://doi.org/10.24141/1/8/1/3

Corresponding author:

Snježana Schuster

A: Mlinarska cesta 38, 10000 Zagreb, Croatia

E-mail:snjezana.schuster@zvu.hr

T: +385914595731 


\section{Introduction}

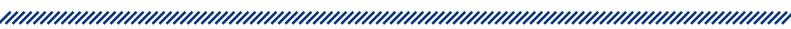

Distance education, also called online education, or online learning, generally refers to a network-based learning activity by which the teachers and students can carry out teaching and learning through internet. Distance education can be categorized as either synchronous or asynchronous. Synchronous technology allows for "live" interaction between the instructor and the students (e.g., audioconferencing, videoconferencing, web chats). Asynchronous technology involves significant delays in time between the instruction and its receipt (e.g., e-mail, earlier video recording, sharing videolinks, books or other sources in discussion forums). ${ }^{1}$

Distance education, which was implemented as a supportive form of education in the past years, has become more important with the impact of the coronavirus pandemic all over the world. However, during lockdown period for stopping the pandemic in the early 2020, online education became the only applicable way to continue the teaching and learning in the universities and colleges. The coronavirus pandemic led to a global transition from in-person to online instruction for many universities or higher education institutions which had little time or not enough training for this responsibility. The coronavirus pandemic forced higher education institutions to consider, not whether quality education could be delivered virtually, but how to implement online teaching and learning in a short period of time. ${ }^{2}$

In Turkey, since March 23, 2019, education had passed gradually to distance education at all educational levels, including physiotherapy and rehabilitation study programs at universities due to Covid 19. ${ }^{3}$ The first case of SARS-CoV-2 infection in Croatia was confirmed on February 25, 2020. ${ }^{4}$ Based on the decision of the Croatian government, all institutions implemented e-learning only, starting with March 16, $2020 .^{5}$

In this article, what will be reviewed is the distance education system in the universities and the integration process of distance education into study programs of physiotherapy and rehabilitation in Turkey and Croatia where emergency distance education was implemented due to the COVID-19 outbreak. The results of this system taken from the surveys and feedback of students and teachers in Turkey and Croatia will also be discussed comparetively and future recommendations on distance education in physiotherapy will be given as common conclusion.

\section{Distance Education System in Turkey}

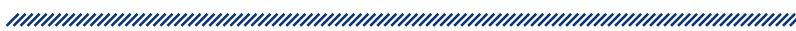

The first distance education system in higher education in Turkey was established with Anadolu University Open Education Faculty in 1981 and it provides all education programs only through distance learning. In 1998, Middle East Technical University has launched the first e-learning classes and courses as a supportive learning method. In the first quarter of 2016 in Turkey, there were 100 Distance Education Centres and 3 Open Education Faculties in 193 universities and almost all of them were at health sciences faculties. ${ }^{6-7}$

However, distance education systems were not so common in health sciences including physiotherapy in Turkey. Distance education in physiotherapy or other health sciences in Turkey had been used within a limited context although physiotherapy practices have integrated distance education, telerehabilitation and telemedicine systems into the treatment in the fields of professional practice for years..$^{8-9}$ However, this alternative education opportunity has become an area open to both support and criticism regarding the provision of equal opportunities in education. ${ }^{10}$

The treatment systems in which all these internet technologies are used, and physiotherapy students' learning and satisfaction with internet technologies in different courses and fields have been evaluated in various studies. ${ }^{11-12}$ In one of the studies in 2017, before the coronavirus pandemic in Turkey, the authors aimed to examine the web-based teaching experiences of physiotherapy and rehabilitation students and one of the courses had been given as a web-based course for 14 weeks. It was found that web-based teaching did not cause a significant difference in students' attitudes. There was no significant difference in terms of gender in student attitudes towards web-based teaching. However, in the study, various advantages, disadvantages, shortcomings and individual contributions of students were evaluated; advantages such as time, space independence, development of research skills, development of technology use, learning different methods, and disadvantages such as various connection problems, failure to adopt the method, concentration problems, have been reported. In addition, students reported that web-based teaching could be used for theoretical courses in physiotherapy and rehabilitation education, but it would not be suitable for practical courses. ${ }^{13}$ 
Although these systems have been taking used in universities as a supportive learning method before, the fact that higher education institutions had to adapt all contents and forms of physiotherapy education in the pandemic period, especially for practical training, using only distance education system, has created various challenges. ${ }^{3,14}$

Universities with distance education units, in particular, have been enabled to plan and implement their educational activities by using their own infrastructure. The National Higher Institution of Education has provided a flexibility to the universities either prefer complete distance educaton or hybrid education dependent upon their curricula. Also, it has recommended that universities check whether physical conditions of every department can allow for enough physical distance to prevent for virus transmision in the pandemic period. ${ }^{3}$

Dependent upon the physical situation and number of the students, each department of the universities have decided their preference - either complete or hybrid distance education system. Only 7 out of 78 physiotherapy schools prefered to keep the face to face education system because they have very limited number of students, enough preventive equipment and ideal physical conditions. However, physical therapy education programs in most of the physiotherapy schools which prefered complete or hybrid distance education were especially impacted since large part of the development of the skills in physiotherapy is based on face-to-face onsite practice. Thus there has been a dramatic change in the learning structure of the first 3 years of physiotherapy and rehabilitation students due to digital platforms replacing face-to-face learning in Turkey.

Although these innovations might have given to students some level of flexibility and efficiency they prefer significantly, keeping high-impact educational practices was particularly challenging with a transition to fully remote learning in physiotherapy education. Many educational activities, including practice education, clinical education experiences, and internships had to be postponed. Alternative platforms for the 4th year students who were supposed to have an internship program in the clinical units of physiotherapy schools or departments of the university hospitals were also largely unavailable. The interns were not accepted to the units, hospitals, clinics, rehabilitation centers or other clinical placements because they could not be vaccinated yet. Thus, many of the interns had scenario-based or problem-based clinical education on interactive platforms with peers and teachers.

According to one of the study results on distance education system during the pandemic in Turkey, the physiotherapy students accessed classes by using the computer, phone and tablet respectively. Female students preferred computers, and male students preferred phones. In 4th year students, in case of online participation in distance education, a significant difference was found compared to other classes. $87.5 \%$ of students found the efficiency of distance education low for practical courses and $78.5 \%$ for theoretical courses. $90.3 \%$ of the students preferred formal education, while $9.7 \%$ preferred distance education. ${ }^{15-16}$

On the other hand, some students of health sciences during the pandemic stated that the chance of continuing education without restriction of place and time is the biggest advantage of distance education. ${ }^{17}$ Although the integration and satisfaction of the educational process, which is carried out asynchronously with the use of virtual classrooms, with the use of synchronous, recording and sharing materials in theoretical fields ${ }^{10}$ is inspiring, it requires dealing with some limitations, especially in the schools for health sciences or the division of the faculties where practical training is at the forefront. ${ }^{17-19}$

In accordance with this perspective of practical skills, $84.4 \%$ of physiotherapy students in Turkey stated that web-based education is not as effective as faceto-face education, $45.7 \%$ of them stated that this is an alternative in the pandemic period. The physioterapy students reported the most contribution to theoretical knowledge and the least contribution to professional practice skills. They also reported that they could not communicate comfortably with the instructors $(49.9 \%)$, that web-based education allowed them to learn at their own pace $(60.7 \%)$, but what was learned was quickly forgotten (74.6\%), and that they experienced technical problems during the training $(53.9 \%){ }^{20}$

In a recent study in Turkey, they have aimed to evaluate the learning styles of students of Nursing, Social Work, and Physiotherapy and Rehabilitation departments at the same university. A total of 246 second-year students have been included in the study and they have used introductory features form and Felder and Soloman Learning Style Inventory as the assessment tool. It was determined that $85.84 \%$ of nursing students, $43.78 \%$ of physiotherapy students and $83.05 \%$ of so- 
cial worke students used the visual learning method. $83,78 \%$ of physiotherapy students, $89.38 \%$ of nursing students and $76.27 \%$ of social work students were using the method of learning by feeling. While $58.11 \%$ of physiotherapy students and $52.21 \%$ of nursing students were using the learning by doing method, $57.63 \%$ of social work students were using learning by thinking method. It was observed that $69.91 \%$ of nursing students, $60.81 \%$ of physiotherapy students and $64.41 \%$ of social work students were using sequential learning method. It is concluded that all three student groups in health sciences use visual, emotional and sequential learning methods intensively. However, physiotherapy students and nursing students were more prone to use the learning by doing method. Students of social work tended to use learning by thinking, although they were using this method less often. The authors stated that learning methods used by the students of the three departments in health sciences show similarities and differences. For this reason, it is thought that choosing the ideal teaching methods and materials in accordance with the learning style predominantly used by each health science students, and even not being limited to a single method, but reflecting the preferred methods in a combination in course plan may be beneficial in increasing the effectiveness of learning. ${ }^{21}$ In another study which evaluated the results of distance education of audilogy and audology students' opinons on distance learning, the participants stated that distance learning contributed the most to their theoretical knowledge and the least to their professional skills. Positive contribution of distance learning to theoretical knowledge was found to be significantly greater in 4th year students than 1st and 2 nd year students. ${ }^{22} \mathrm{~A}$ related study which aimed to investigate audiology students' opinions about virtual internship who used the virtual audiometer program during their summer internship, the intern students indicated that this alternative approach may support the reinforcement of clinical skills, despite having limitations of interactions with patients. ${ }^{23}$ Following the study results, there could be some differences of learning methods even between the students of health sciences. Thus, each deparment in health sciences has to work to find out the most appropriate and ideal learning program which is required for their professional skills and competences.

Learning is very much a social phenomenon where interaction and collaboration between learners and tutors embedding feedback. ${ }^{24}$ However, distance education or e-learning system is often viewed as a technology rather than pedagogy, as it mostly drives learning through technology, compromising the needs and expectations of learners. Besides, there are several factors, including appropriate policies and strategies, adequate resources and trained staff in place that might interplay in making e-learning or online education effective.

A systematic review has identified the factors which have an impact on e-learning: interaction and collaboration between learners and facilitators: considering learners' motivation and expectations, utilising userfriendly technology, and putting learners at the centre of pedagogy. There is significant scope for better understanding of the issues related to enablers and facilitators associated with e-learning, and developing appropriate policies and initiatives to establish when, how and where they fit best, creating a broader framework for making e-learning effective. ${ }^{18}$

The available evidence suggests that making e-learning effective in the health sciences is affected not only by the lack of resources - significant time and cost savings and support, but also that design aspects should be taken into account in creating or promoting self- directed learning especially in practical courses. At the same time, appropriate development of institutional strategies is paramount. This could include such elements as flexibility and access, learning styles, costs, and integration to promote learners' knowledge and understanding evidence-based national drivers and local contexts, putting learners' learning experience as the main driver. While analysing reported factors, two groups of factors as internal and external factors appeared commonly. Internal factors refer to the poor engagement, poor perception and motivation, limited flexibility, high levels of anxiety and stress, lack of students' self-discipline and low self-efficacy, as well as poor interactions between learners and facilitators. Such factors not only hinder the process of learning and motivation but also fail to meet learners' healthcare needs and expectations..$^{25-26}$ External factors are mostly related to the course structure, poor pedagogical design, clarity of the purpose and goal, education management policy, educational paradigms, learners' diversity, current and future education workforce needs, financial independence, influence of national and international policies, lack of learning space, limited use of technology in education, poor evidencebased education and training, and strategic change 
in higher education as well as inadequate support. ${ }^{27-28}$

However, strong evidence of e-learning of health science education and its expectations and the factors concerning e-learning is still limited, scattered and patchy. ${ }^{29-30}$ Therefore, to accelerate the adaptation process to the online education system in physiotherapy, it is needed to determine and evaluate the advantages and disadvantages for physiotherapy students and teachers with for further studies. Furhermore, the universities can enable the development of traditional education system integrated with distance education systems which is called a blended learning model. ${ }^{14}$ As blended learning, which combines faceto-face and online instruction, evolves into the dominant form of instruction throughout all levels of education, it serves as the basis for an integrated model (Figure 1). Blended learning engages with face to-face classrooms, virtual classrooms, hands-on coaching and self-paced learning. ${ }^{31}$ Curriculum and pedagogy can be interlinked by two different learning models as blended learning and flipped classroom. These two models present some degree of interface between learners and philosophy of the learning. Blended learning model is simply an integration of classroom face-to-face learning experiences with on-line learning to facilitate independent, interactive and collaborative learning due to its flexible and technologically rich format. This approach is, however, reported as complex and challenging in nature due to its different possible designs, and contextual needs. Flipped or inverted classroom is a form of blended learning, where students learn partly in class, and partly through on-line learning, providing students more choices in terms of the place and pace of learning experiences. The key factors for success in these models of e-learning or on-line education are to collaborate and integrate e-learning into the current curricula. ${ }^{32-33}$

In a study evaluating the relationship between the learning styles of Turkish physiotherapy students and their academic achievement, it was reported that these students had more cooperative learning styles, but students with participatory learning styles had higher academic achievements. It has been suggested that practices such as classroom activities, discussions and group projects that encourage participatory learning may be beneficial in increasing the academic performance of physiotherapy students. For this reason, it may be beneficial to add such applications to the distance education models created for physiotherapy students. In addition, since most of the physiotherapy students have a collaborative learning style, the active environment and materials that enable students to share and collaborate with teachers and peers in distance education systems can increase the benefits of physiotherapy education. ${ }^{34}$

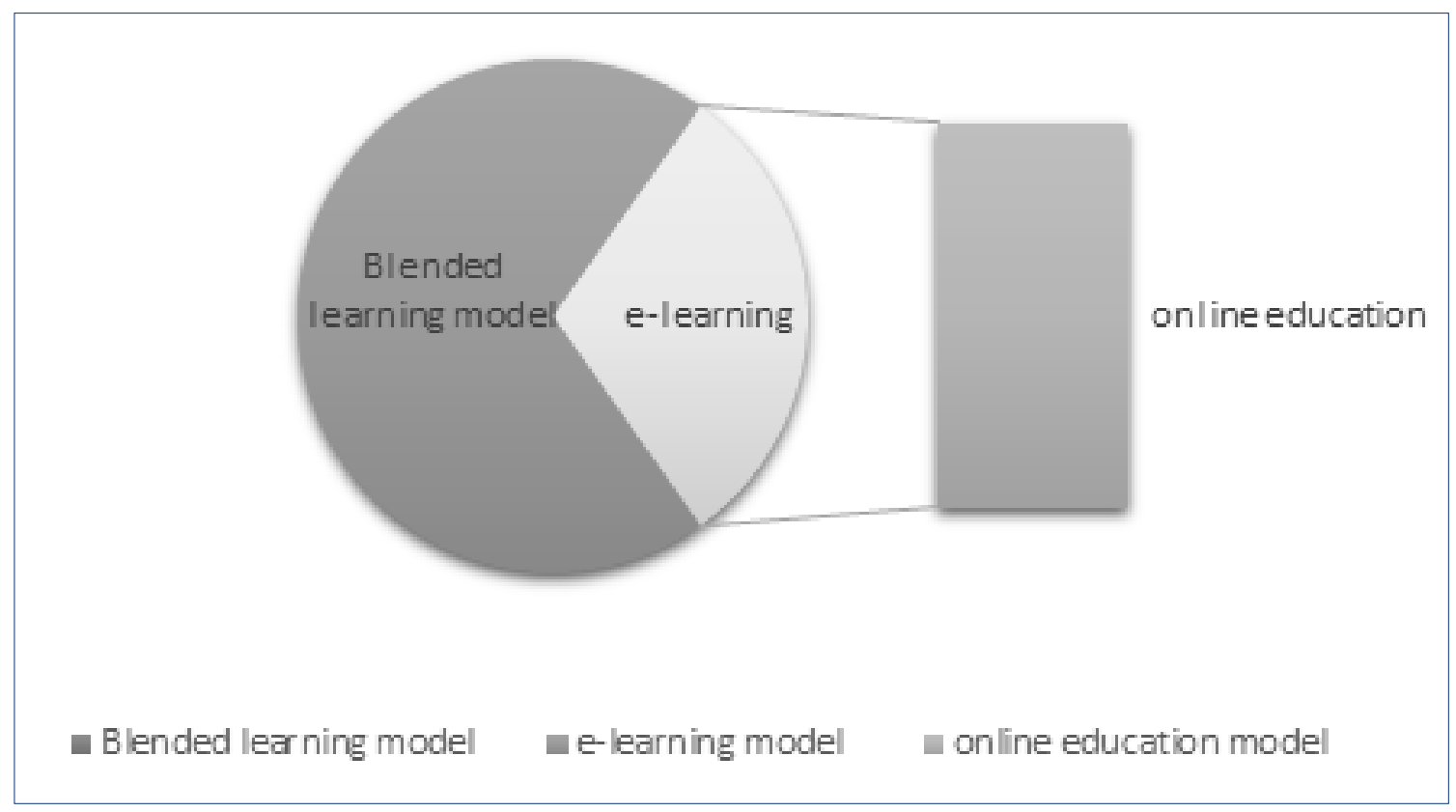

Figure 1. Integrated model -blended learning - face to face and online instruction 


\section{Higher education of healh professionals in Croatia during the pandemic}

None of the higher education institutions provided exclusive e-learning before the pandemic, but all institutions had access to the internet and online tools, including Microsoft Teams, and other similar tools provided by the Croatian government. All institutions have had internet access for years, provided by the Croatian Academic and Research Network (CARNet). In the implementation of health protection of all employees in the higher education system, the recommendations were used regarding SARS-CoV-2 infection. $35,36,37$

According to the survey conducted by $\mathrm{ASHE}^{11}$ among students and teachers, as an advantage, students state saving time, the ability to view teaching content outside the class schedule, and see the shortcomings in an unstable internet connection, differences in teaching preparation and quality of performance by teachers. As shortcomings, teachers stated their constant availability and thus greater teaching load, lack of knowledge of internet technology and its possibilities for teaching, which is why they had to undergo additional education. As advanategs they recognized the easier possibility of monitoring individual student work. ${ }^{38}$

In the higher education area of Croatia in general, the research conducted by ASHE stands out and includes several segments: technological conditions of study, quality of teaching in a virtual environment, evaluation and assessment of student achievement, assessment of students in terms of workload in a virtual environment, socio-psychological aspects of teaching in a virtual environment. ${ }^{38}$

The benefits of saving time are highlighted as the use of technology enables learning and work from home, and thus leaving students and teachers more time for hobbies and other activities. This opens up the possibility of more accessible review of learning materials.

Among the negative aspects, the unstable internet connection that affects the quality of teaching and the unequal ability of teachers to use technology in conducting distance learning stand out. On the other hand, it turned out that teachers have irreplaceable contact with students in the teaching process. ${ }^{38}$
In the segment of evaluation and assessment of student achievements (learning outcomes) in the virtual environment is dominated by negative student experiences and students' resourcefulness in accepting a new way of learning also depended on the organizational skills of students, discipline, etc. ${ }^{38}$

In the segment of socio-psychological aspects of teaching in a virtual environment, some students pointed to the problem

with self-motivation, to which circumstances further contributed such as fear of coronavirus infection, financial crisis, etc.

Among the negative aspects, the employees of higher education institutions mentioned the intertwining of business and private, family obligations while working at home, a large amount of materials and the need to maintain students' interests throughout the semester, and the inability to engage in scientific work due to increased teaching load. Some of them believe that psychological and technical support for teachers and students was lacking at all levels. ${ }^{38}$

In the research regarding the opinions of university students of health sciences conducted by Puljak et al., many students did not express concern due to a lack of practical lessons, voicing opinions that this can be compensated once they start working. ${ }^{5}$ This could indicate that students are underestimating the importance of practical education during their university studies. There are many reasons for the perception of the importance of maintaining practice during education, noting the importance of clinical, practical teaching in relation to theoretical (lectures and seminars). In Croatia, there are differencec between the ratio of theoretical and practical teaching in university and professional physiotherapy educational programs.

The minimum number of hours of clinical practice includes 700 hours in undergraduate studies and is different from the number of hours in graduate studies. Study programs related to physiotherapy professions have developed in different periods according to certain needs for the opening of higher education institutions and such study programs that have been recognized as potential in some regions.

In the combination of completed undergraduate and graduate study of physiotherapy, a sufficient number of hours of clinical training is obtained and thus the acquisition of competencies and learning outcomes for working with patients. 
Precisely because of such a difference and the insufficient hours of clinical training in undergraduate study programs, there is a problem of obtaining a license to work abroad and certain countries even require additional work with patients before obtaining licence for independent work.

Another significant reason that leads to such attitudes in the perception of the importance of clinical, practical teaching, can be observed through the curriculum load or how much clinical teaching is realized or planned, which may affect students' opinions about the importance of clinical teaching or practice.

In study programs where clinical teaching was less represented during the pandemic, especially during lockdown, it was minimized or it was not face-to-face. Published materials, videos and the like were used as an additional substitute tool in teaching for the implementation of planned teaching in clinics.

Until the outbreak of the pandemic, such teaching materials served as supplementary materials but not as the main way of performing clinical practice. Students who did not encounter physiotherapy during their secondary education, and due to the absence of clinical practice during their undergraduate education, could gain the impression of such teaching as being less important.

However, students' interest in mixed forms of teaching implementation prevails. In the future changes of the teaching process and regarding the acquisition of competencies for clinical work, the hours of clinical practice should not be reduced in the new models, whether they of a hybrid form, online or remote.

Most students indicated that in the future, they would prefer to combine traditional classroom and e-learning ( $N=1403 ; 55.7 \%), 25.4 \%(N=641)$ preferred to continue with traditional classroom learning and $18.9 \%(\mathrm{~N}=476)$ would continue with e-learning only. ${ }^{5}$
Some research before the global pandemic and lockdown highlights the results of the attitudes of students and bachelors of physiotherapy who believe that practical knowledge during education should be more emphasized in relation to theoretical knowledge. ${ }^{13}$

In some study programs, there is a mismatch between the knowledge they gain in education and the practical work that students encounter on the job sites.

Hours of clinical teaching in most higher education study programs for physiotherapists in Croatia (Table 1) range from 630 to 700 hours $^{39}$, which is not sufficient compared to other European study programs, which include about 1000 hours. However, part of the teaching is carried out on the premises of the universities which are equipped for pre-clinical acquisition of knowledge and skills in physiotherapy, and this part of the teaching, although pre-clinical, increases the hours of practical teaching.

Generally, the hours of practical classes on the university premises range from 350-500 hours during the undergraduate study of physiotherapy, which in combination with clinical training raises the total hours of practical classes to match the European average, which means about 1000 hours.

In Croatia, due to the binary education system, there is a problem of emphasizing the difference between professional and university study programs that differ in practical clinical teaching as well as practical demonstration rooms, so the question of the need to harmonize clinical teaching in university and professional study programs arises because competencies for working with patients ultimately need to be acquired.

In this part, there is no significant difference between professional and university study programs, although the perception of university students shows less importance of clinical training (Table 1 ) during a pandemic. ${ }^{5}$

\begin{tabular}{l}
$\begin{array}{l}\text { Table 1. Overview of the relationship between the teaching hours of clinical practice } \\
\text { of the physiotherapy study program and the opinions of students } \\
\text { in Turkey and Croatia on distance education }\end{array}$ \\
$\begin{array}{l}\text { Turkey } \\
\text { Croatia }\end{array}$ \\
$\begin{array}{c}\text { Clinical practice - physiotherapy } \\
\text { Prefer only distance education } \\
\text { in the future }\end{array}$ \\
\hline
\end{tabular}




\section{Conclusion}

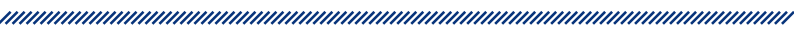

Students in Croatia should have a clear perception of the importance of practical, clinical teaching in which they acquire competencies for working with patients, users and clients alongside courses that are part of basic physiotherapy covered through the theory of physiotherapy.

An open question remains for further research in Croatia, considerng the causes that led to the perception of clinical teaching being less important than theoretical. The pandemic period in Croatia showed the need to unify study programs (professional and university) and to form a unique program for higher education of physiotherapists at the entry level.

In Turkey, it is considered that it is important to develop the existing solution for applied courses and internship programs or to find alternative methods for them. Theoretical knowledge does not make sense to the physiotherapy students until they apply their knowledge and skills in the clinical environment. It is well known that clinical education of physiotherapy students with the traditional methods promotes exposure of students to real-life scenarios and helps future clinicians to develop essential skills. In addition to internship programs in real clinical enviroments, hands-on practicing in the classroom or clinical practice education under the supervison of a teacher is the most crucial part of physiotherapy education in Turkey as well as Croatia.

Taking into account this main feature of physiotherapy profession, the distance education system of physiotherapy in Turkey and Croatia have to be developed to find an existing solution of applied courses and clinical education and also alternative internship programs or clinical placements. To accelerate the adaptation process of the distance education system in physiotherapy, the advantages and disadvantages for the students and the teachers need to be determined and to evaluated. How physiotherapy students perceive distance education and their expectations should be evaluated in the light of various subconcepts that affect learning, such as intrinsic and extrinsic motivational factors. Universities may enable the development of traditional education system in physiotherapy by being supported by distance education systems. In this context, developing systems in the field of physiotherapy as more effective and supportive for practical training, revising the curriculum, providing innovations such as pedagogical support and developing a new system in the future will be necessary. This can be achieved by using a blended learning model which is also called the integrated learning system. It is thought that blended education in which face-to-face and distance education are carried out together especially for applied courses will be a more effective method for learning success in physiotherapy. Increasing future studies in the field of distance education, developing educational content using more sensory stimuli, supporting the infrastructure and making more use of the power of technology may enable the strengths of distance education to be integrated into traditional education systems in physiotherapy.

\section{References}

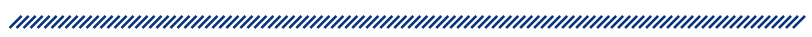

1. Hrastinski, S. Asynchronous and synchronous e-learning. Educause Quarterly, 2008; 31(4), 51-55.

2. Adedoyin OB, Soykan E. Covid-19 pandemic and online learning: the challenges and opportunities. Interactive Learning Environments, 2020; DOI: 10.1080/10494820.2020.1813180)

3. YÖK. (2020a, 3 Nisan). Üniversitelerde uygulanacak uzaktan eğitime ilişkin açıklama. 3 Nisan 2020. https:// www.yok.gov.tr/Sayfalar/Haberler/2020/

4. Chronology of epidemics development. In Croatian. Available at: https://www.koronavirus.hr/. Accessed 15 March 2020.

5. Puljak et al. Attitudes and concerns of undergraduate university health sciences students in Croatia regarding complete switch to e-learning during COVID-19 pandemic: a survey. BMC Med Educ 2020 Nov 10;20(1):416. doi: 10.1186/s12909-020-02343-7.

6. Kırkan B, Kalelioğlu F. Situation of Distance Education Centers in Turkey: A Descriptive Study. Journal of Instructional Technologies \& Teacher Education 2017; 6 (3):88-98).

7. Bozkurt, ATürkiye'de uzaktan eğitimin dünü, bugünü ve yarını. Açıköğretim Uygulamaları ve Araştırmaları Dergisi, 2017; 3(2), 85-124.

8. Pınar Bölüktaş R, Özer Z, Yıldırım D. Web Tabanlı Eğitimin Sağlık Alanında Kullanılabilirliği 1. Uluslararası Yönetim ve Sosyal Araştırmalar Dergisi. 2019; 6(11):197-207.

9. Özden F, Arık AF, Tuğay N. Current Telerehabilitation Approaches in Orthopaedic Physiotherapy. Turkiye Klinikleri Journal of Health Sciences. 2020; 5(2):354-60.)

10. Balıkçıoğlu N, Çınar Öz D, Işın NN. Üniversite öğrencilerinin uzaktan eğitim derslerindeki memnuniyet araştırması: Aşık Veysel Meslek Yüksekokulu örneği. Cumhuriyet Üniversitesi İktisadi ve İdari Bilimler Dergisi 2019;20(1):462- 473. 
11. Evans C, Yeung E, Markoulakis R, Guilcher S. An online community of practice to support evidence-based physiotherapy practice in manual therapy. Journal of Continuing Education in The Health professions 2014;34(4):215223.

12. Hossain MS, Shofiqul Islam M, Glinsky JV, Lowe R, Lowe T, Harvey LA. A massive open online course (MOOC) can be used to teach physiotherapy students about spinal cord injuries: a randomised trial. Journal of Physiotherapy 2015;61(1):21-27.

13. Özüdoğru G, Özüdoğru A. Fizyoterapi ve rehabilitasyon öğrencilerinin web tabanlı öğretim deneyimlerinin incelenmesi. Ahi Evran Üniversitesi Kırşehir Eğitim Fakültesi Dergisi 2017;18(3):865-879.

14. Bulut S, Özbek H, Soysal-Tomruk M, Tomruk M. Emergency distance education and integration process in physiotherapy. Curr Perspect Health Sci, 2020;1(1): 19-24.

15. Altuntaş Yılmaz N. Investigation of Students' Attitudes Towards Applied Distance Education in The Covid-19 Pandemic Process in Higher Education Institutions: Example of Physiotherapy and Rehabilitation Department. Necmettin Erbakan University Faculty of Health Sciences Journal 2020; 3 (1): 15-20.

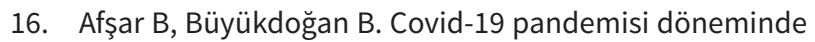
iiBF ve SBBF öğrencilerinin uzaktan eğitim hakkındaki değerlendirmeleri. Karatay Sosyal Araştırmalar Dergisi 2020; 5:161-182.

17. Terzi D, Akalın RB, Erdal B. Covid-19 salgınının sağlık alanındaki öğrencilerin eğitimine etkisi: Tekirdağ Namık Kemal Üniversitesi Sağlık Hizmetleri Meslek Yüksekokulu örneği. Namık Kemal Tıp Dergisi 2020; 8(3):279-287.

18. Regmi K, Jones L. A systematic review of the factors Enablers and barriers - Affecting e-learning in health sciences education. BMC Medical Education. 2020; 20(1) 91-96.

19. McCutcheon LRM, Alzghari SK, Lee YR, Long WG, Marquez R. Interprofessional education and distance education: a review and appraisal of the current literature. Curr Pharm Teach Learn 2017; 9(4): 729-736.

20. Keskin M, Özer Kaya D. Evaluation of Students' Feedbacks on Web-Based Distance Education in the Covid-19 Process. İzmir Kâtip Çelebi Üniversitesi Sağlık Bilimleri Fakültesi Dergisi 2020; 5(2): 59-67.

21. Koşar Şahin C et al. Comparative Evaluation of Learning Styles of Nursing, Social Work And Physiotherapy and Rehabilitation Department Students. Int. Anatolia Academic Online Journal (Health Sciences) 2021, 7(1):144-160.

22. Özses $M$, Dinçer D’Alessandro $H$, Özbal Batuk $M$, Sennaroğlu G. Audiology students opinions on distance learning during the Covid-19 Pandemic: Experince from Hacettepe Üniversity. Turk J Audiol Hearing Res 2021; 4(1):11-17.

23. Koska, B, Dinçer D’Alessandro, H, Özbal Batuk, M, Sennaroğlu, G. COVID-19 pandemisi sürecinde uzaktan odyoloji eğitimi: Sanal staj hakkındaki öğrenci görüşleri. Turk J Audiol Hearing Res, 2021; 4(1):18-24.
24. Reeves PM, Reeves TC. Design considerations for online learning in health and social work education. Learn Health Soc Care. 2008; 7:46-58.

25. Gagnon M, Legare F, Labrecque M, Fremont P, Cauchon $M$, Desmartis MA. Perceived barriers to completing an elearning program on evidence-based medicine. Inform Prim Care. 2007; 15: 83-91.

26. Kokol P, Blazun H, Micetić-Turk D, Abbott PA. E-Learning in nursing education- challenges and opportunities. Stud Health Technol Inform. 2006; 122:387-90.

27. Hammarlund CS, Nilsson MH, Gummesson C. External and internal factors influencing self-directed online learning of physiotherapy undergraduate students in Sweden: a qualitative study. J Educ Eval Health Prof. 2015; 12:33-37.

28. Gormley GJ, Collins K, Boohan M, Bickle IC, Stevenson M. Is there a place for e-learning in clinical skills? A survey of undergraduate medical students' experiences and attitudes. Med Teach. 2009; 3: e6-e12.

29. Kim S. The future of e-learning in medical education: current trend and future opportunity. J Contin Educ Health Prof. 2006; 3:3-7.

30. Ruiz JG, Mintzer MJ, Leipzig RM. The impact of E-learning in medical education. Acad Med. 2006; 8:207-12.

31. Walsh K. Blended learning. BMJ. 2005; 330:829-832.

32. Morton CE, Saleh SN, Smith SF, Hemani A, Ameen A, Bennie TD. Blended learning: how can we optimise undergraduate student engagement? BMC Med Educ. 2016; 16:195-199.

33. Garrison DR, Kanuka H. Blended learning: uncovering its transformative potential in higher education. Internet High Educ. 2004; 7:95-105.

34. Ilçin M, Tomruk N, Yeşilyaprak SS, Karadibak D, Savcı S. The relationship between learning styles and academic performance in Turkish physiotherapy students. Physiotherapy. 2016;102: e 84-5.

35. https://mzo.gov.hr/UserDocslmages/dokumenti/Obrazovanje/VisokoObrazovanje/Preporuke_COVID_19_ sveucilista_20_05-1.pdf Accessed 30 March 2021.

36. https://www.srce.unizg.hr/ceu/upute-i-preporuke-zaonline-nastavu/ Preporuke visokim učilištima vezano uz organizaciju obrazovnog procesa na daljinu uz pomoć informacijske tehnologije, (pripremilo Srce za MZO) - 11. ožujka 2020. Accessed 30 March 2021.

37. MZO. Akcijski plan za provedbu nastave na daljinu. srpanj 2020. Accessed 20 March 2021.

38. AZVO. Izazovi u visokom obrazovanju za vrijeme pandemije bolesti COVID-19 i socijalne izolacije: iskustva i potrebe studenata i djelatnika visokih učilišta. Zagreb, rujan 2020. Accessed 25 March 2021.

39. Jurički D, Petrak O, Schuster S (2021). Opinions of students and bachelors of physiotherapy on theoretical and practical teaching. J. appl. health sci.; 7(2): 167-179 


\section{SUSTAV OBRAZOVANJA NA DALJINU U FIZIOTERAPIJI I REHABILITACIJI U TURSKOJ I HRVATSKOJ}

1 Filiz Can

2 Snježana Schuster

1 Hacettepe University Faculty of Physical Therapy and Rehabilitation, Ankara, Turkey

2 Zdravstveno veleučilište Zagreb, Katedra za fizioterapiju, Zagreb, Hrvatska

\section{Sažetak}

"

Obrazovanje na daljinu, koje se posljednjih godina primjenjivalo kao oblik obrazovanja, postalo je važnije s utjecajem pandemije izazvane virusom SARS-CoV-2 u cijelom svijetu. U Turskoj se od 23. ožujka 2019. zbog pandemije postupno primjenjivalo obrazovanje na daljinu na svim obrazovnim razinama, uključujući fakultete za fizioterapiju i rehabilitaciju na sveučilištima. $\mathrm{Na}$ Sveučilištu za obrazovanje na daljinu u Turskoj postoje 123 jedinice. $87,5 \%$ studenata mišljenja je da je učinkovitost obrazovanja na daljinu niska, posebno u praktičnoj nastavi, dok 9,7 \% studenata preferira obrazovanje na daljinu. Studenti smatraju najmanjim doprinos nastave na daljinu u području vještina i profesionalne prakse. Prvi slučaj infekcije virusom SARS-CoV-2 u Hrvatskoj potvrđen je 25. veljače 2020. U istraživanju koje su Puljak i suradnici proveli o mišljenjima sveučilišnih studenata zdravstvenih znanosti, mnogi studenti nisu izrazili zabrinutost zbog nedostatka praktične nastave, izražavajući mišljenja da se to može nadoknaditi kad počnu raditi. Većina studenata mišljenja je da bi u budućnosti trebalo kombinirali klasičnu nastavu i e-učenje ( $N=1403 ; 55,7 \%$ ). Dobiveni rezultati otvaraju pitanja percepcije studenata o važnosti praktične nastave tijekom sveučilišnog studija. Sustav obrazovanja na daljinu u području fizioterapije i rehabilitacije u Turskoj i Hrvatskoj utjecat će na revidiranje kurikuluma i primjenu kombiniranog modela učenja (engl. blended learning) koji se naziva i integriranim sustavom učenja.

Ključne riječi: visoko obrazovanje, obrazovanje na daljinu, fizioterapija, Turska, Hrvatska 